\title{
Methane potential of fruit and vegetable waste: an evaluation of the semi-continuous anaerobic mono-digestion
}

Thiago Edwiges, Laercio Mantovani Frare, João Henrique Lima Alino, Jin Mi Triolo, Xavier Flotats \& Mônica Sarolli Silva de Mendonça Costa

To cite this article: Thiago Edwiges, Laercio Mantovani Frare, João Henrique Lima Alino, Jin Mi Triolo, Xavier Flotats \& Mônica Sarolli Silva de Mendonça Costa (2018): Methane potential of fruit and vegetable waste: an evaluation of the semi-continuous anaerobic mono-digestion, Environmental Technology, DOI: 10.1080/09593330.2018.1515262

To link to this article: https://doi.org/10.1080/09593330.2018.1515262

Accepted author version posted online: 22

Aug 2018.

Submit your article to this journal $₫$

ఋ Article views: 2

View Crossmark data ¿ 
Publisher: Taylor \& Francis \& Informa UK Limited, trading as Taylor \& Francis Group Journal: Environmental Technology

DOI: 10.1080/09593330.2018.1515262

Check for updates

Methane potential of fruit and vegetable waste: an evaluation of the semicontinuous anaerobic mono-digestion

Author: Thiago Edwiges (corresponding author)

Department of Biological and Environmental Sciences

Federal University of Technology - Parana

E-mail: thiagoe@,utfpr.edu.br

Address: Avenida Brasil 4232, 85884-000 - Medianeira, Brazil

Phone: +554532408000

Author: Laercio Mantovani Frare

Department of Biological and Environmental Sciences

Federal University of Technology - Parana

E-mail: laercio@utfpr.edu.br

Author: João Henrique Lima Alino

Department of Biological and Environmental Sciences

Federal University of Technology - Parana

E-mail: joaoalino94@gmail.com

Author: Jin Mi Triolo

Department of Chemical Engineering, Biotechnology and Environmental Technology

University of Southern Denmark

E-mail: jmt@kbm.sdu.dk

Author: Xavier Flotats

GIRO joint research unit IRTA/UPC - Department of Agri-Food Engineering and

Biotechnology

Polytechnic University of Catalonia

E-mail: xavier.flotats@upc.edu 
Author: Mônica Sarolli Silva de Mendonça Costa

Center of Exact and Technological Sciences State University of Western Parana

E-mail: monica.costa@unioeste.br

\title{
Methane potential of fruit and vegetable waste: an evaluation of the semi- continuous anaerobic mono-digestion
}

\begin{abstract}
The anaerobic digestion (AD) of a high diversity blend of fruit and vegetable waste (FVW) generated in tropical conditions as a single substrate was performed. A continuously stirred tank reactor (CSTR) operated in semi-continuous regime was used for AD. The reactor performance was monitored with gradually increasing organic loading rates (OLRs) from $0.5 \mathrm{gVS} \mathrm{L}^{-1} \mathrm{~d}^{-1}$ up to $5.0 \mathrm{gVS} \mathrm{L}^{-1} \mathrm{~d}^{-1}$. The biochemical methane potential (BMP) of FVW determined by batch bottles was $360 \mathrm{~L}_{\mathrm{N}} \mathrm{CH}_{4} \mathrm{~kg}_{\mathrm{vs}}{ }^{-1}$, with a biodegradability of $79 \%$. A stable $\mathrm{pH}$ with an adequate level of buffering capacity was observed during the entire experiment. Methane yield indicated the best performance at an OLR of $3.0 \mathrm{gVS} \mathrm{L}^{-1} \mathrm{~d}^{-1}$, with $285 \mathrm{~L}_{\mathrm{N}} \mathrm{CH}_{4} \mathrm{~kg}_{\mathrm{Vs}}{ }^{-1}$ added, reaching $79 \%$ of BMP. At an OLR over $3.0 \mathrm{gVS} \mathrm{L}^{-1} \mathrm{~d}^{-1}$ accumulation of volatile fatty acids (VFA) was detected; in particular, propionic acid was monitored, and a decreased methane yield was detected. Biogas production rate was $1.55 \mathrm{~L}_{\mathrm{N}} \mathrm{L}^{-1} \mathrm{~d}^{-1}$ and showed linear increase according to increases in the OLR.
\end{abstract}

Keywords: biogas; BMP; biodegradability; CSTR; organic loading rate.

\section{Introduction}

Around 173 million inhabitants live in the urban perimeter of Brazil. Regarding the municipal solid waste (MSW) generated in the Brazilian urban area, less than $10 \%$ is properly treated or recycled and only $53 \%$ of it is disposed in adequate sanitary landfills [1]. Controlling the use of non-regulated landfills is still a challenge in the country and the lack of drainage systems for gases and leachates in these areas represents high environmental impact [2].

Due to the adequate climate and water availability, tropical countries are responsible for an expressive amount of fruits and vegetables. Brazil occupies the 
leading position of this market, being the largest fruit and vegetable producer in the world [3]. To allow the commercialization of farm products, the Brazilian government has been implementing several public wholesale markets since 1970; nowadays, more than 60 of them are operating in all regions of the country [4].

As fruit and vegetable waste (FVW) has high content of water and rapid hydrolysable sugars, negative impacts such as strong odour, leachate production, and disposal costs are often reported $[5,6]$. Anaerobic digestion (AD) of organic waste is a widely applied technology, and its main beneficial properties include the ability to treat high moisture-containing biomasses and small-scale applicability. In recent years, AD has been gaining more appeal, and its application has been emerging noticeably due to the increasing demand for renewable energy [7].

The operation of mono-digestion using FVW as a single substrate is often reported as an unstable process because of simple sugar degradation, volatile fatty acids (VFA) accumulation, and subsequently, fast system acidification. The AD of FVW used as a single substrate has been limited to an organic loading rate (OLR) under $3.5 \mathrm{gVS} \mathrm{L}^{-}$ ${ }^{1} \mathrm{~d}^{-1}[8,9,10]$. Several studies haye described the AD of FVW $[10,11,12]$, but only a few have used FVW as a single substrate. Alvarez and Lidén [13] and Jiang et al. [9] reported the failure of AD using only FVW due to VFA accumulation and subsequent $\mathrm{pH}$ reduction. Strategies used in these studies to promote a more stable digestion include the use of co-substrates and a solution of trace elements. To contribute to adequate chemical characteristics and avoid a high content of simple sugars, codigestion with animal manure, sewage sludge, and other organic co-substrates has been used often. Unfortunately, due to logistical and economic issues, it is not always possible to guarantee suitable amounts of co-substrates as a feedstock [14]. 
The adoption of two-stage $\mathrm{AD}$ reactors has also been reported as a strategy to improve the process stability of substrates rich in simple sugars, as they allow the buffering of the OLR in the first stage and a more constant feeding rate in the methanogenic second stage. However, more complex and expensive treatment plants are required for this sort of operation. Ganesh et al. [8] and Shen et al. [15] evaluated the AD of FVW in both single-stage and two-stage reactors and reported the advantages of single-stage digestion due to simpler operation requirements, higher methane yields, and better economic benefits.

A better solution for preventing acidification effects may be the use of a wellbalanced mixture of FVW, increasing the diversity of fruit and yegetable types in the substrate, therefore avoiding the use of those rich in simple sugars [14]. Thus, the aim of this study was to perform the anaerobic mono-digestion of a well-diversified blend of FVW generated in tropical conditions by applying different organic loading rates to evaluate system performance.

\section{Materials and methods}

\subsection{Feedstock and seeding sludge}

The mixture of FVW used as a substrate was collected from a municipal wholesale market (Foz do Iguaçu, Brazil). The market generates around 2,800 kg d $\mathrm{d}^{-1}$ of solid waste, with $85 \%$ of its organic content being sent to landfill weekly. A representative sample of $20 \mathrm{~L}$ was collected at 6 different points of the waste container after a week (November 2016) and before its final destination. In total, 33 types of fruits and vegetables composed the mixture and qualitative composition indicated that $48 \%$ were fruit and $52 \%$ were vegetable waste based on the total amount of registered types. High diversity in the mixture was observed, as no type of fruit or vegetable represented more than $7 \%$ (wet basis) of the total amount (Figure 1). 
Each type of collected fruits and vegetables was weighed and the mixture was grinded without water addition to preserve the sample characteristics, with particle size under $10 \mathrm{~mm}$. The sample was then frozen at $-18{ }^{\circ} \mathrm{C}$, and the amount needed to feed the digester for one week was thawed and stored at $+4{ }^{\circ} \mathrm{C}[16]$.

\section{(Figure 1 near here)}

As mesophilic biogas plants are not common in Brazil, the inoculum used for batch and semi-continuous tests was prepared with a mixture of two digestates (one from a biogas plant processing swine manure and cattle manure) and raw cattle manure, from the western region of the state of Paraná/Brazil. Maintenance of the biological activity of inoculum was performed by weekly feeding with a mixture of substrates at an OLR of $0.5 \mathrm{gVS} \mathrm{L}^{-1} \mathrm{~d}^{-1}$ [17]. Feeding was interrupted one week before the inoculum was used to respect the degassing period. Further information on the maintenance and composition of the inoculum is described in Edwiges et al. [18].

\subsection{Batch assay}

Biochemical methane potential (BMP) of the FVW mixture was determined in batch bottles $(200 \mathrm{~mL})$ coupled to eudiometer-graduated tubes $(300 \mathrm{~mL})$ and expressed in $\mathrm{L}_{\mathrm{N}} \mathrm{CH}_{4} \mathrm{~kg} \mathrm{VS}$ added. BMP of the mixture was determined to compare the batch and semi-continuous potential. The biological activity of the inoculum was assessed using microcrystalline cellulose as a reference sample (Sigma-Aldrich, $20 \mu$ diameter).

The solid content in batch bottles was kept according to the guidelines proposed by VDI 4630 (2006) to provide standardized results. The average value for total solids (TS) in the mixture (inoculum + substrate) contained in the batch bottles was around $4.1 \%$; volatile solids (VS) related to inoculum was $1.9 \%$ average and the inoculum-tosubstrate ratio based on VS was greater than 2. Nitrogen gas was flushed into each bottle to expel its oxygen content and temperature was controlled at $37 \pm 2{ }^{\circ} \mathrm{C}$ by a 
regulated water bath. Biogas production was daily registered until it represented less than $1 \%$ of accumulated biogas [16].

The biodegradability of FVW was evaluated indirectly through the relation between theoretical BMP (TBMP) and measured BMP. A detailed method for the estimation of TBMP is found in Triolo et al. [19].

\subsection{Reactor design and operational conditions}

Semi-continuous $\mathrm{AD}$ was performed in a continuously stirred tank reactor (CSTR) (B Braun Biotech-Biostat B) with double-walled glass and a 4 L working volume (Figure 2). Mesophilic temperature was controlled at $37 \neq 2{ }^{\circ} \mathrm{C}$ by a thermostatically regulated water bath, and stirring speed was kept at $60 \mathrm{~min}^{-1}$ to ensure adequate mixing and degassing. The anaerobic reactor was filled with $75 \%$ of precultivated seeding sludge (as described in Section 2.2) and $25 \%$ of distilled water. Digestate feeding and discharging were carried out on a daily basis. For acclimatization of the microbial population to the feeding substrate, the digester was operated in a batch system for two weeks with $V \mathrm{~S}_{\mathrm{FVW}} / \mathrm{VS}_{\text {inoculum }}=0.1$. Biogas volume was measured through an inverted beaker filled with an acid sealing solution $(\mathrm{pH}<2.0)$.

\section{(Figure 2 near here)}

The initial OLR of $0.5 \mathrm{gVS} \mathrm{L}^{-1} \mathrm{~d}^{-1}$ was then used for 20 days during the start-up phase, with a hydraulic retention time (HRT) of 40 days [15]. Afterwards, the HRT was decreased to 30 days and substrate was fed in OLR's of 0.5, 1.0, 1.5, 2.0, 2.5, 3.0, 3.5, 4.0 and $5.0 \mathrm{gVS} \mathrm{L}^{-1} \mathrm{~d}^{-1}$ with a transitional slope, i.e. the increased amount of VS added per day during 5 days, of $0.1 \mathrm{gVS} \mathrm{L}^{-1} \mathrm{~d}^{-1}$, except for the last OLR, when $0.2 \mathrm{gVS} \mathrm{L}^{-1} \mathrm{~d}^{-}$

${ }^{1}$ was used (Figure 4c). As VDI 4630 [16] suggest increasing the loading rate as soon as methane production is constant for at least four days (empirical value), this strategy was adopted. Additionally, the statistical coefficients of variation $\left(\mathrm{C}_{\mathrm{var}}\right)$ of daily methane 
production for each OLR was introduced to determine the ability of digestion system for new-fed substrate through the variability of data $[10,15]$. The OLR was then changed whenever $\mathrm{C}_{\mathrm{var}}$ was under $10 \%$.

The OLR employed in this study was based on the VS of fresh feedstock. Distilled water was used to prepare the initial feeding loads to maintain the HRT constant while variating the OLR. Thus, it was possible to evaluate the methane potential of only FVW with the same operational conditions, avoiding the effect of any co-substrates. For the last OLR, the system was operated with an HRT of 24 days due to the higher feeding rate needed to achieve $5.0 \mathrm{gVS} \mathrm{L}^{-1} \mathrm{~d}^{-1}$.

Biogas was drained using an outlet pipe at the top of the reactor, and volumetric production was daily measured through a graduated test tube, where an acid solution was used as a sealing liquid. The measured volume was corrected to dried biogas at normal temperature and pressure conditions [16].

\subsection{Analytical methods and process monitoring}

Total solids (TS), volatile solids (VS), $\mathrm{pH}$, total alkalinity (TA), crude lipid, and total Kjeldahl nitrogen (TKN) were determined according to the standard methods [20]. Crude protein was estimated by multiplying TKN by 6.25 [21]. Partial alkalinity (PA), intermediate alkalinity (IA) and volatile acids (VA) in the digestate were determined according to Ripley et al. [22] and DiLallo and Albertson [23] to evaluate the monitoring process. The VA was determined by titration to a $\mathrm{pH}$ endpoint of 5.75 in order to express the ratio between total alkalinity/volatile acids (VA:TA), which can express the buffering contribution of bicarbonate during $\mathrm{AD}$ when it is under 0.3 .

The VFA of the digestate was detected using high-performance liquid chromatography in a Shimadzu-2010 system equipped with an AminexHPX-87H column (300 mm long and $4.6 \mathrm{~mm}$ internal diameter BioRad) and an ultraviolet detector 
with a diode arrangement, based on the methodology proposed by Lazaro et al. [24]. Methane concentration was determined by gas chromatography (Perkin Elmer-Clarus 680) using a thermal conductivity detector and a $30 \mathrm{~m}$ long packed Plot Q column packed with $0.32 \mathrm{~mm}$ internal diameter. Helium was used as carrier gas with a flow rate of $30 \mathrm{~mL} \mathrm{~min}^{-1}$.

Cellulose, hemicellulose, and lignin were determined through neutral detergent fibre (NDF), acid detergent fibre (ADF), and acid detergent lignin (ADL) [25], Nonlignocellulosic carbohydrate was estimated by the difference between 100 and the sum of proteins, lipids, water, ashes, and lignocellulose. Trace elements of FVW and digestate were measured through atomic absorption spectrometry (Digimed DM-62) after nitro-perchloric digestion.

\section{Results and discussion}

\subsection{Substrate and inoculum characteristics}

The concentration of solids in the FVW mixture was similar to the ones found in the literature $[8,12]$, showing high values for moisture and volatile compounds (TS: $129 \mathrm{~g} \mathrm{~kg}^{-1}$; VS: $121 \mathrm{~g} \mathrm{~kg}^{-1}$ ). These characteristics indicate the potential for biological treatment, fitting AD for waste treatment and bioenergy production. However, $\mathrm{pH}$ wwas 3.9 (Table 1), which may indicate limitation of AD due to methanogenesis.

\section{(Table 1 near here)}

Organic compounds were similar to those reported by Shen et al. [15] and Wang et al. [10]. Non-lignocellulosic carbohydrates were the most common among organic components $(55.2 \%)$, indicating the potential for a fast conversion of organic matter into biogas. Regarding lignocellulose content $(26.3 \%)$, the characteristics were more similar to those green grasses when compared to cellulosic biomass, e.g., agricultural 
residues and wild plants [19], showing its potential for high methane production yields through AD.

The inoculum characteristics were TS $5.8 \pm 0.1 \%$, VS $62.3 \pm 1.3 \%$ of TS, and the $\mathrm{pH}$ was of $8.3 \pm 0.1$. These main characteristics indicate an adequate level of microorganisms indicated by VDI 4630 [16] and a slightly alkaline medium. Total alkalinity was of $8.900 \pm 94 \mathrm{mg} \mathrm{CaCO}_{3} \mathrm{~L}^{-1}$.

\subsection{Biochemical methane potential}

BMP measured from batch bottles was $360 \pm 2 \mathrm{~L}_{\mathrm{N}} \mathrm{CH}_{4} \mathrm{kgvs}^{-1}$ added, similar to that found by Jiang et al. [9] of $350 \mathrm{~L}_{\mathrm{N}} \mathrm{CH}_{4} \mathrm{~kg}_{\mathrm{Vs}}{ }^{-1}$ added while evaluating the $\mathrm{AD}$ of a vegetable mixture composed by beans, corn, carrots, and broccoli. Lin et al. [5] reported lower BMP of $300 \mathrm{~L}_{\mathrm{N}} \mathrm{CH}_{4} \mathrm{~kg}_{\mathrm{Vs}}{ }^{-1}$ added of a more diversified mixture of fruits and vegetables composed of cabbages, carrots, lettuces, apples, bananas, pears, and watermelons. Even so, the BMP of FVW was relatively high when compared to other organic substrates, such as 243,303 , and $268 \mathrm{~L} \mathrm{CH}_{4} \mathrm{~kg}_{\mathrm{Vs}}{ }^{-1}$ added of dairy manure [26], swine manure [27] and food waste [28], respectively.

The estimation of TBMP through chemical composition resulted in $456 \mathrm{~L}_{\mathrm{N}} \mathrm{CH}_{4}$ $\mathrm{kg}_{\mathrm{VS}}{ }^{-1}$. Thus, biodegradability estimated by the relation between BMP/TBMP was $79 \%$, which was remarkably higher than the values for other types of organic substrates. Triolo et al. [19] reported a $68 \%$ average of biodegradability for vegetable biomass, such as grass and wheat straw, and a $49 \%$ average for animal biomass such as cattle and pig manure. Cumulative methane (Figure 3) showed a fast conversion of FVW into biogas, in which more than $90 \%$ of organic matter was degraded in the first 5 days of the batch test. This fast methane production of FVW might be related to the organic composition, which mainly contained non-lignocellulosic carbohydrates (52.2\%). 


\subsection{Biogas production rate and methane yield}

During the start-up period, biogas production rate was between $0.20 \pm 0.02 \mathrm{~L}_{\mathrm{N}}$ $\mathrm{L}^{-1} \mathrm{~d}^{-1}$ (Figure 4a), with slightly lower production during the first OLR $\left(0.5 \mathrm{gVS} \mathrm{L}^{-1} \mathrm{~d}^{-}\right.$ ${ }^{1}$ ) (phase I) as a result of the HRT difference, which was of 40 days and 30 days, respectively. Later, the biogas rate increased according to a subsequent increase in OLR from 1.0 to $5.0 \mathrm{gVS} \mathrm{L}^{-1} \mathrm{~d}^{-1}$, achieving $1.55 \pm 0.12 \mathrm{~L}_{\mathrm{N}} \mathrm{L}^{-1} \mathrm{~d}^{-1}$ (Table 2). This productivity was much higher when compared to other types of substrate, such as animal manure. Negral et al. [29] reported biogas productivity of only $0.3 \mathrm{~L} \mathrm{~L}^{-1} \mathrm{~d}^{-1}$ using raw dairy manure as a substrate at an OLR of $2.3 \mathrm{gVS} \mathrm{L}^{-1} \mathrm{~d}^{-1}$. However, when using the liquid fraction of dairy manure, Rico et al. [30] reported biogas productivity similar to the one found in this study $\left(1,47 \mathrm{~L} \mathrm{~L}^{-1} \mathrm{~d}^{-1}\right)$, as similarly to $\mathrm{FVW}$, the liquid fraction of dairy manure presents high content of easily biodegradable compounds.

\section{(Figure 4 near here)}

Statistical $\mathrm{C}_{\mathrm{var}}$ were under $10^{\circ} \%$ of each OLR (Table 2), indicating data homogeneity during each operational phase. The highest $\mathrm{CV}$ variation was obtained until day 62, corresponding to an OLR of $1.5 \mathrm{gVS} \mathrm{L}^{-1} \mathrm{~d}^{-1}$ (phase III), as bacterial activity was being adjusted to operational conditions such as type of substrate and increasing OLR at the beginning of AD. Similarly, methane concentration in the biogas presented the lowest values at the beginning of the process, due to the low content of soluble organic matter in the inoculum.

\section{(Table 2 near here)}

Daily methane yield ranged from $151 \pm 12 \mathrm{~L}_{\mathrm{N}} \mathrm{CH}_{4} \mathrm{~kg}_{\mathrm{Vs}}{ }^{-1}$ to $285 \pm 10 \mathrm{~L}_{\mathrm{N}} \mathrm{CH}_{4}$ $\mathrm{kg}_{\mathrm{VS}}{ }^{-1}$ added (Table 2), showing the best efficiency values at an OLR of $3.0 \mathrm{gVS} \mathrm{L}^{-1} \mathrm{~d}^{-1}$ (phase VI). Di Maria and Barratta [12] reported a similar methane yield of $236 \mathrm{~L}_{\mathrm{N}} \mathrm{CH}_{4}$ $\mathrm{kg}_{\mathrm{VS}}{ }^{-1}$ during the $\mathrm{AD}$ of a mixture of organic substrate composed of potatoes $(55 \%)$, 
FVW (28\%), bread (5\%), paper (2\%), and pasta $(10 \%)$ at an OLR of $2.8 \mathrm{gVS} \mathrm{L}^{-1} \mathrm{~d}^{-1}$ and HRT of 35 days. A higher methane yield of $352 \mathrm{~L}_{\mathrm{N}} \mathrm{CH}_{4} \mathrm{~kg}_{\mathrm{Vs}}{ }^{-1}$ was reported by Jiang et al. [9] while evaluating AD of FVW at an OLR of $3.0 \mathrm{gVS} \mathrm{L}^{-1} \mathrm{~d}^{-1}$ and a HRT of 26 days. The substrate used was composed of beans (75\%), baby corn (19\%), carrots $(3 \%)$, and broccoli $(3 \%)$ and a solution of trace elements was weekly added proportionally to $1 \mathrm{~mL} \mathrm{~L}^{-1}$ to achieve process stability. These studies highlight the limitations of AD with FVW as a single substrate concerning the OLR.

After an OLR of $3.5 \mathrm{gVS} \mathrm{L}^{-1} \mathrm{~d}^{-1}$ (phase VII) methane yield showed a constant decrease, starting on day 102 (Figure 4a). This behaviour might indieate the load limit of the anaerobic mono-digestion of FVW concerning conversion efficiency. Even with the downward trend starting on phase VII, the operation was kept until an OLR of 5.0 gVS L $\mathrm{L}^{-1}$ (phase IX) as the biogas rate showed linear growth $\left(\mathrm{R}^{2} 0.94\right)$ with the increase in OLR. Phase IX presented methane yield of $198 \pm 17 \mathrm{~L}_{\mathrm{N}} \mathrm{CH}_{4} \mathrm{~kg}_{\mathrm{Vs}}{ }^{-1}$ added, this value being $21 \%$ lower than the one for the best production achieved and therefore, the AD process was interrupted at day 143 . However, data on biogas production rate can provide useful information on the operational planning of biogas plants, as the system showed the ability to withstand the higher OLR.

The methane yield produced from CSTR achieved an average of $62 \%$ of measured BMP determined in batch bottles. The best performance was obtained at an OLR of $3.0 \mathrm{gVS} \mathrm{L}^{-1} \mathrm{~d}^{-1}$ (phase VI), in which $79 \%$ of BMP was achieved. Methane content ranged from $45 \%$ to $65 \%$ until day 62 , and from $67 \%$ to $75 \%$ until day 133 (Table 2). During phase IX, when the OLR increased from 4.0 to $5.0 \mathrm{gVS} \mathrm{L}^{-1} \mathrm{~d}^{-1}$ and the HRT consequently reduced from 30 to 24 days, a drop in the methane content was observed. This can initially indicate inhibition in the methanogenic activity, as an accumulation of VFA was equally observed during this phase. However, as stated by 
Rico et al. [31], increases in OLR and decreases in HRT may also contribute to lower methane content in the biogas. Furthermore, the higher methane content in the biogas between the OLR of 2.0 and $4.0 \mathrm{gVS} \mathrm{L}^{-1} \mathrm{~d}^{-1}$ was also associated to high alkalinity availability inside the reactor (Figure 4b), which is responsible for withholding carbon dioxide in its dissolved forms, i.e. $\mathrm{H}_{2} \mathrm{CO}_{3}, \mathrm{HCO}_{3}{ }^{-}, \mathrm{CO}_{3}{ }^{-2}$.

\subsection{Digestate characteristics}

During the digestion process, the $\mathrm{pH}$ of the digestate was in the range of 7.9 and 8.3 (Table 2), not showing a tendency to acidification with the increase of OLR. The concentration of total VFA in the digestate ranged from 22 to $390 \mathrm{mg}$ - -1 , along with an increase from 0.5 to $3.0 \mathrm{gVS} \mathrm{L}^{-1} \mathrm{~d}^{-1}$ in the OLR (Table 2). Thereafter, a considerably later increase was observed, with VFA reaching $1,781 \mathrm{mg} \mathrm{L}^{-1}$ at the OLR of $5.0 \mathrm{gVS} \mathrm{L}^{-}$ ${ }^{1} \mathrm{~d}^{-1}$ (Figure 5a), due to the high soluble carbohydrates composition of FVW.

The accumulation of VFA after OLR of $3.0 \mathrm{gVS} \mathrm{L}^{-1} \mathrm{~d}^{-1}$ is a sign of instability, as we can see in the reduction of biogas yield and methane concentration after this period. The propionic acid content represented most of the VFA content, showing an average of $51 \%$, reaching $63 \%$ for the OLR at $5.0 \mathrm{gVS} \mathrm{L}^{-1} \mathrm{~d}^{-1}$ (Figure $5 \mathrm{~b}$ ). Shen et al. [15] and Wang et al. [10] have similarly reported accumulation of VFA during AD of FVW, mainly as propionic acid.

\section{(Figure 5 near here)}

Even with VFA accumulation, the $\mathrm{pH}$ was kept in a slightly alkaline range, mainly because of its buffering capacity of the bicarbonate/carbon dioxide equilibrium

[5]. Total alkalinity was sufficiently high during $\mathrm{AD}$, with a concentration above $2.6 \mathrm{~g}$ $\mathrm{CaCO}_{3} \mathrm{~L}^{-1}$ for OLR values ranging from 0.5 to $2.5 \mathrm{gVS} \mathrm{L}^{-1} \mathrm{~d}^{-1}$ (Figure $4 \mathrm{~b}$ ). After an OLR of $3.0 \mathrm{gVS} \mathrm{L}^{-1} \mathrm{~d}^{-1}$, total alkalinity was above $3.5 \mathrm{~g} \mathrm{CaCO}_{3} \mathrm{~L}^{-1}$, increasing to $6.4 \mathrm{~g}$ $\mathrm{CaCO}_{3} \mathrm{~L}^{-1}$ until the end of the operation. This can be mainly explained by the alkalinity 
produced by ammonium bicarbonate, whose ammonia $\left(\mathrm{NH}_{3}\right)$ released from the degradation of proteins and amino acids reacted with carbon dioxide and water, providing alkalinity to the system (Equation 1).

$$
\mathrm{NH}_{3}+\mathrm{CO}_{2}+\mathrm{H}_{2} \mathrm{O} \rightarrow \mathrm{NH}_{4} \mathrm{HCO}_{3}
$$

During the entire experiment, both IA:PA and VA:TA ratios were consistently below 0.3 (Table 2), showing the buffering contribution of bicarbonate and indicating a scenario of stable operation. However, as the VFA started to accumulate after an OLR of $3.5 \mathrm{gVS} \mathrm{L}^{-1} \mathrm{~d}^{-1}$ (Figure 4c), these ratios did not seem to reflect its initial inhibition aspect. The concentration of acetic acid and butyric acid of 2,400 and $1,800 \mathrm{mg} \mathrm{L}^{-1}$, respectively, were not reported in the literature as inhibitors. On the other hand, propionic acid concentration of $900 \mathrm{mg} \mathrm{L}^{-1}$ resulted in the significant inhibition of the methanogens. As stated by Wang et al. [32], the propionic conversion rate to methane is slower than the acetic and butyric acids. Thus, propionic acid accumulation results in methanogenic inhibition in concentrations lower than those of other organic acids.

\section{(Figure 5 near here)}

The concentration of acetic and butyric acid in this study was below $500 \mathrm{mg} \mathrm{L}^{-1}$ during the entire experiment, but the concentration of propionic acid was considerably high $\left(1,113 \mathrm{mg} \mathrm{L}^{-1}\right.$ at an OLR of $\left.5.0 \mathrm{gVS} \mathrm{L}^{-1} \mathrm{~d}^{-1}\right)$, indicating the degradation of propionic acid had is slowed down, which was probably due to accumulation of $\mathrm{H}_{2}$, as degradation of propionic acid is thermodynamically unpreferable with $\mathrm{H}_{2}$ accumulation. The accumulation of propionic acids can also be affected by the lack of trace elements, as anaerobic biochemical reactions, including the conversion of organic acids into methane, requires essential enzymes containing metals such as cobalt, nickel, iron, and zinc molybdenum and tungsten [9]. However, as can been see in Table 3, the content of the metals was sufficient, showing that mono-digestion of FVW does not require trace 
metal supply. This was observed by Williams et al. [33], who reported biogas production stimulation by adding extra $0.59 \mathrm{mg} \mathrm{L}^{-1}$ of nickel, while its concentration on digestate was of $14.8 \mathrm{mg} \mathrm{L}^{-1}$. Ortner et al. [34] also reported only $62 \%$ of $\mathrm{Ni}$ and Co bioavailability of total concentration while investigating the influence of trace elements on $\mathrm{AD}$ of slaughterhouse waste.

(Table 3 near here)

\section{Conclusions}

The results of this study have demonstrated that mesophilic anaerobic monodigestion of a highly diverse mixture of fruits and vegetables is possible. These results highlight the potential use of a biomass source that is not so common used in developing countries. A stable process operation was observed at an OLR of up to 5 $\mathrm{gVS} \mathrm{L}^{-1} \mathrm{~d}^{-1}$, with highest rate of biogas production achieved at $1.55 \mathrm{~L} \pm 0.12 \mathrm{~L}^{-1} \mathrm{~d}^{-1}$ and HRT of 24 days. However, the highest efficiency rate regarding the specific methane yield was obtained at an OLR of $3 \mathrm{gVS} \mathrm{L}^{-1} \mathrm{~d}^{-1}$, with $285 \pm 26 \mathrm{~L}_{\mathrm{N}} \mathrm{CH}_{4} \mathrm{~kg}_{\mathrm{Vs}}{ }^{-1}$. VFA accumulation, especially propionic acid with concentrations above $1,000 \mathrm{mg} \mathrm{L}^{-1}$ was detected in the last OLR, indicating the operational limits of the anaerobic monodigestion process for this type of biomass.

\section{References}

[1] Brazilian Ministry of Cities. [National Information System on Sanitation: Management Diagnosis Urban Solid Waste 2015]. Brasília: 2017. Portuguese.

[2] Leme, M. M. V., Rocha, M. H., Lora, E. E. S., Venturini, O. J., Lopes, B. M., Ferreira, C. H. Techno-economic analysis and environmental impact assessment of energy recovery from Municipal Solid Waste (MSW) in Brazil. Resour. Conserv. Recy. $2014 ; 87: 8-20$. 
[3] FAO. Food and Agriculture Organization of the United Nations. FAO statistical yearbook 2014: Latin America and the Caribbean food and agriculture. 2014.

[4] Brazilian Ministry of Agriculture Livestock and Food Supply. Institutional history]. Brasília: 2017. Portuguese.

[5] Lin, J., Zuo, J., Gan, L., Li, P., Liu, F., Wang, K., Chen, L., Gan, H. Effects of mixture ratio on anaerobic co-digestion with fruit and vegetable waste and food waste of China. J. Environ. Sci-China. 2011;23:1403-1408.

[6] Qiao, W., Yan, X., Ye, J., Sun, Y., Wang, W., Zhang, Z. Evaluation of biogas production from different biomass wastes with/without hydrothermal pretreatment. Renew. Energ. 2011;36:3313-3318.

[7] Appels, L., Lauwers, L., Degrève, J., Helsen, L., Lievens, B., Willems, K., Van Impe, J., Dewil, R. Anaerobic digestion in global bio-energy production: Potential and research challenges. Renew. Sust. Energ. Rev. 2011;15:4295-4301.

[8] Ganesh, R., Torrijos, M., Soubie, P., Lugardon, A., Steyer, J. P., Delgenes, J. P. Single-phase and two-phase anaerobic digestion of fruit and vegetable waste: comparison of start-up, reactor stability and process performance. Waste Manage. $2014 ; 34: 875-885$.

[9] Jiang, Y. Heave, S., Banks, C. J. Strategies for stable anaerobic digestion of vegetable waste. Renew. Energ. 2012;44:206-214.

[10] Wang, L., Shen, F., Yuan, H., Zou, D., Liu, Y., Zhu, B., Li, X. Anaerobic codigestion of kitchen waste and fruit/vegetable waste: Lab-scale and pilot-scale studies. Waste Manage. 2014;34:2627-2633.

[11] Bouallagui, H., Lahdehb, H., Ben Romdan, E., Rachdi, B., Hamdi, M. Improvement of fruit and vegetable waste anaerobic digestion performance and stability with co-substrates addition. J. Environ. Manage. 2009;90:1844-1849. 
[12] Di Maria, F., Barratta, M. Boosting methane generation by co-digestion of sludge with fruit and vegetable waste: internal environment of digester and methanogenic pathway. Waste Manage. 2015;43:130-136.

[13] Alvarez, R., Lidén, G. Semi-continuous co-digestion of solid slaughterhouse waste, manure, and fruit and vegetable waste. Renew. Energ. 2008;33:726-734.

[14] Scano, E. A., Asquer, C., pistis, A., Ortu, L., Demontis, V., Cocco, D. Biogas from anaerobic digestion of fruit and vegetable wastes: Experimental results on pilot-scale and preliminary performance evaluation of a full-scale power plant. Energ. Convers. Manage. 2014;77:22-30.

[15] Shen, F., Yuan, H., Pang, Y., Chen, S., Zhu, B., Zou, D., Liu, Y., Ma, J., Yu, L., Li, X. Performances of anaerobic co-digestion of fruit \& vegetable waste (FVW) and food waste (FW): Single-phase vs. two-phase. Bioresource Technol. 2013;144:80-95.

[16] VDI 4630, 2006. Fermentation of organic materials: characterization of the substrate, sampling, collection of material data, fermentation tests. In: Verein Deutscher Ingenieure, Berlin, Germany.

[17] Steinmetz, R. L. R., Mezzari, M. P., Da Silva, M. L. B., Kunz, A., Amaral, A. C., Tápparo, D. C., Soares, H. M. Enrichment and acclimation of an anaerobic mesophilic microorganism's inoculum for standardization of BMP assays, Bioresource Technol. $2016 ; 219 ; 21-28$.

[18] Edwiges, T.; Frare L.; Mayer, B.; Lins, L.; Triolo, J. M.; Flotats, X.; Costa, M. S. S. M. Influence of chemical composition on biochemical methane potential of fruit and vegetable waste. Waste Manage. 2017;71:618-625.

[19] Triolo, J. M., Pedersen, L., Qu, H., Sommer, S. G. Biochemical methane potential and anaerobic biodegradability of non-herbaceous and herbaceous phytomass in biogas production. Bioresource Technol. 2012;125:226-232. 
[20] APHA. Standard Methods for the Examination of Water and Wastewater. American Public Health Association, DC. 2005.

[21] FAO. Food and Agriculture Organization of the United Nations. Food and nutrition paper 77: food energy (methods of analysis and conversion factors). 2002.

[22] Ripley, L. E., Boyle, W. C., Converse, J. C. Improved alkalimetric monitoring for anaerobic digestion of high-strength wastes. J. Water Pollut. Con. F. 1986;58:406-411.

[23] DiLallo, R., Albertson, O. E. Volatile acids by direct titration. J. Water Pollut. Con. F. 1961;33:456-365.

[24] Lazaro, C. Z.; Vich, D. V.; Hirawawa, J. S.; Varesche, M. B. A. Hydrogen production and consumption of organic acids by a phototropic microbial consortium. Int J Hydrogen Energ. 2012;37:11691-11700.

[25] Van Soest, P.J., Robertson, J.B., Lewis, B.A. Methods for dietary fiber, neutral detergent fiber, and nonstarch polysaccharides in relation to animal nutrition. J. Dairy Sci. 1991;74:3583-3597.

[26] Labatut, R. A., Angenent, L. T., Scott, N. R. Biochemical methane potential and biodegradability of complex organic substrates. Bioresource Technol. 2011;102:22552264.

[27] Amaral, A. C., Kunz, A., Steinmetz, R. L. R., Scussiato, L. A., Tápparo, D. C., Gaspareto, T. C. Influence of solid-liquid separation strategy on biogas yield from a stratified swine production system. J. Environ. Manage. 2016;168:229-235.

[28] Bayard, R., Benbelkacem, H., Gourdon, R., Buffière, P. Characterization of selected municipal solid waste components to estimate their biodegradability. J. Environ. Manage. 2017;http://dx.doi.org/10.1016/j.jenvman.2017.04.087. 
[29] Negral, L., Castrillon, L., Marañón, E., Fernandez-Nava, Y., Ormaechea, P. Inverted phase fermentation as a pretreatment for anaerobic digestion of cattle manure and sewage sludge, J. Environ. Manage. 2017;203:741-744.

[30] Rico, C.; Rico, J. L.; Tejero, I.; Muñoz, N.; Gómez, B. Anaerobic digestion of the liquid fraction of dairy manure in pilot plant for biogas production: Residual methane yield of digestate. Waste Manage. 2011;31:2167:2173.

[31] Rico, C.; Muñoz, N.; Rico, J. L. Anaerobic co-digestion of cheese whey and the screened liquid fraction of dairy manure in a single continuously stirred tank reactor process: Limits in co-substrate ratios and organic loading rate. Bioresource Technol. 2015; 189:327-333.

[32] Wang, Y., Zhang, Y., Wang, J., Meng, L. Effects of volatile fatty acid concentrations on methane yield and methanogenic bacteria. Biomass Bioenerg. 2009;33:848-853.

[33] Williams, C. M., Shih, J. C. H. \& Spears, J. W. Effect of nickel on biological methane generation from a laboratory poultry waste digester. Biotechnol. Bioeng. $1986 ; 28: 1608-1610$.

[34] Ortner, M., Rameder, M., Rachbauer, L., Bochmann, G., Fuchs, W. Bioavailability of essential trace elements and their impact on anaerobic digestion of slaughterhouse waste. Biochem. Eng. J. 2016;99:107-113.

[35] Pinto-Ibieta, F., Serrano, A., Jeison, D., Borja, R., Fermoso, F. G. Effect of cobalt supplementation and fractionation on the biological response in the biomethanization of Olive Mill Solid Waste. Bioresource Technol. 2016;211:58-64.

[36] Zhang, Y., Zhang, Z., Suzuki, K., Maekawa, T. Uptake and mass balance of trace metals for methane producing bacteria. Biomass Bioenerg. 2003;25:427-433. 
[37] Evranos, B., Demirel, B. The impact of Ni, Co and Mo supplementation on methane yield from anaerobic mono-digestion of maize silage. Environ. Technol. 2015;36:1556-1562.

[38] Mao, C. Feng, Y. Wang, X. Ren, G. Review on research achievements of biogas from anaerobic digestion. Renew. Sust. Energ. Rev. 2015;45:540-555.

\section{FIGURE CAPTIONS}

- $\quad$ Figure 1. Qualitative composition of FVW (\%) used as substrate.

- $\quad$ Figure 2. Experimental set up scheme.

- Figure 3. Cumulative methane production of FVW. Methane production from FVW was expressed subtracting the endogenous production related to inoculum.

- Figure 4. Biogas rate $(\rightarrow)$ (left) and methane yield $(-\infty)$ (right) during different operational phase (a); total alkalinity $(\bullet)$ (left) and $\mathrm{pH}$ of digestate $(\circ)$ (right) during different operational phases (b); start period of each OLR tested during the operational phase ( $($ ) (left) and methane content of biogas ( $O$ ) (right) during each operational phase (c). OLR was $0.5,0.5,1.0,1.5,2.0,2.5,3.0,3.5,4.0$ and $5.0 \mathrm{~g}$ SV $\mathrm{L}^{-1} \mathrm{~d}^{-1}$ for operational phase I, II, III, IV, V, VI, VII, VIII, IX, and X, respectively.

- Figure 5. Concentration of VFA (a) and percentage of each VFA related to total concentration (b) during different operational OLR. 


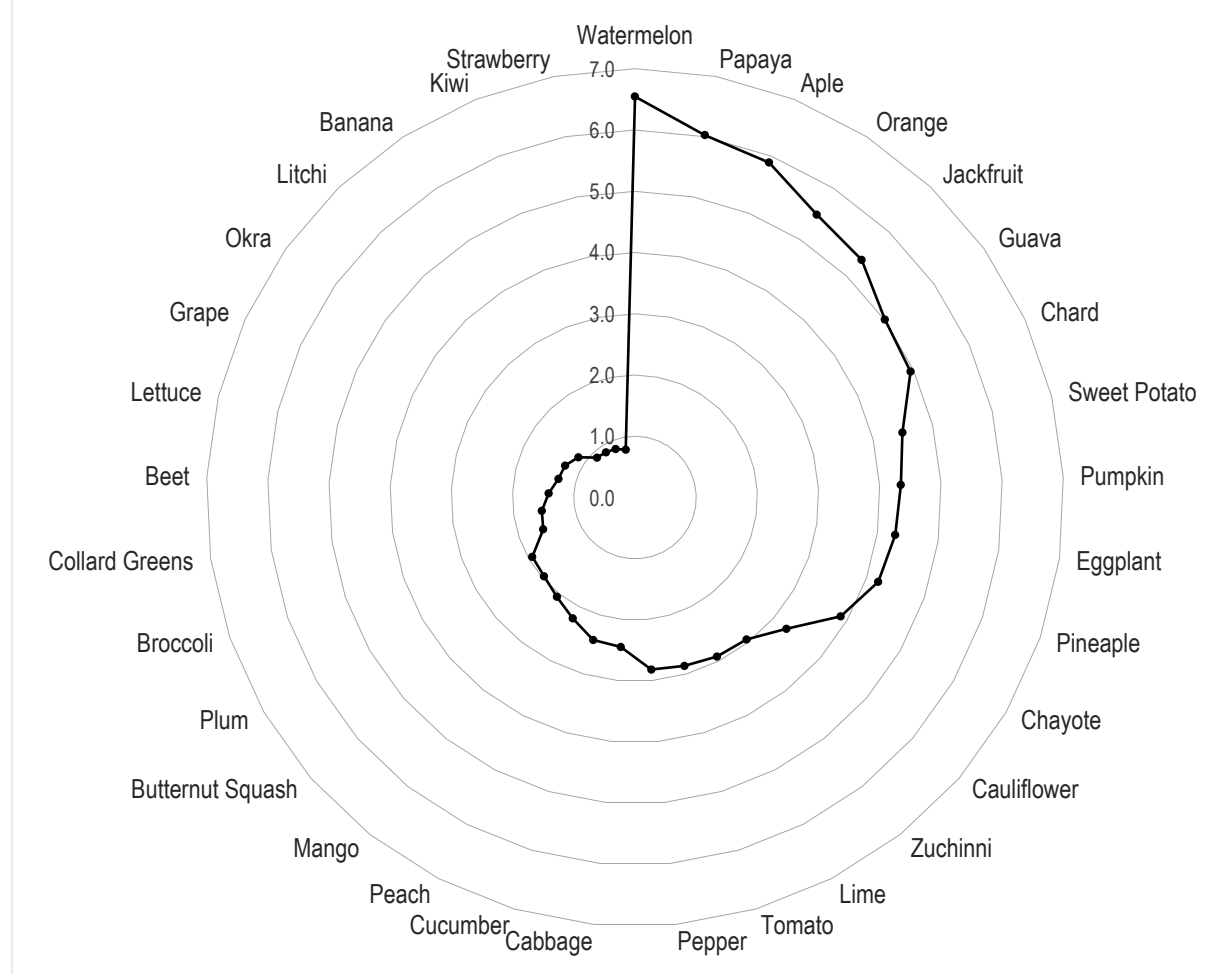

Figure 1.
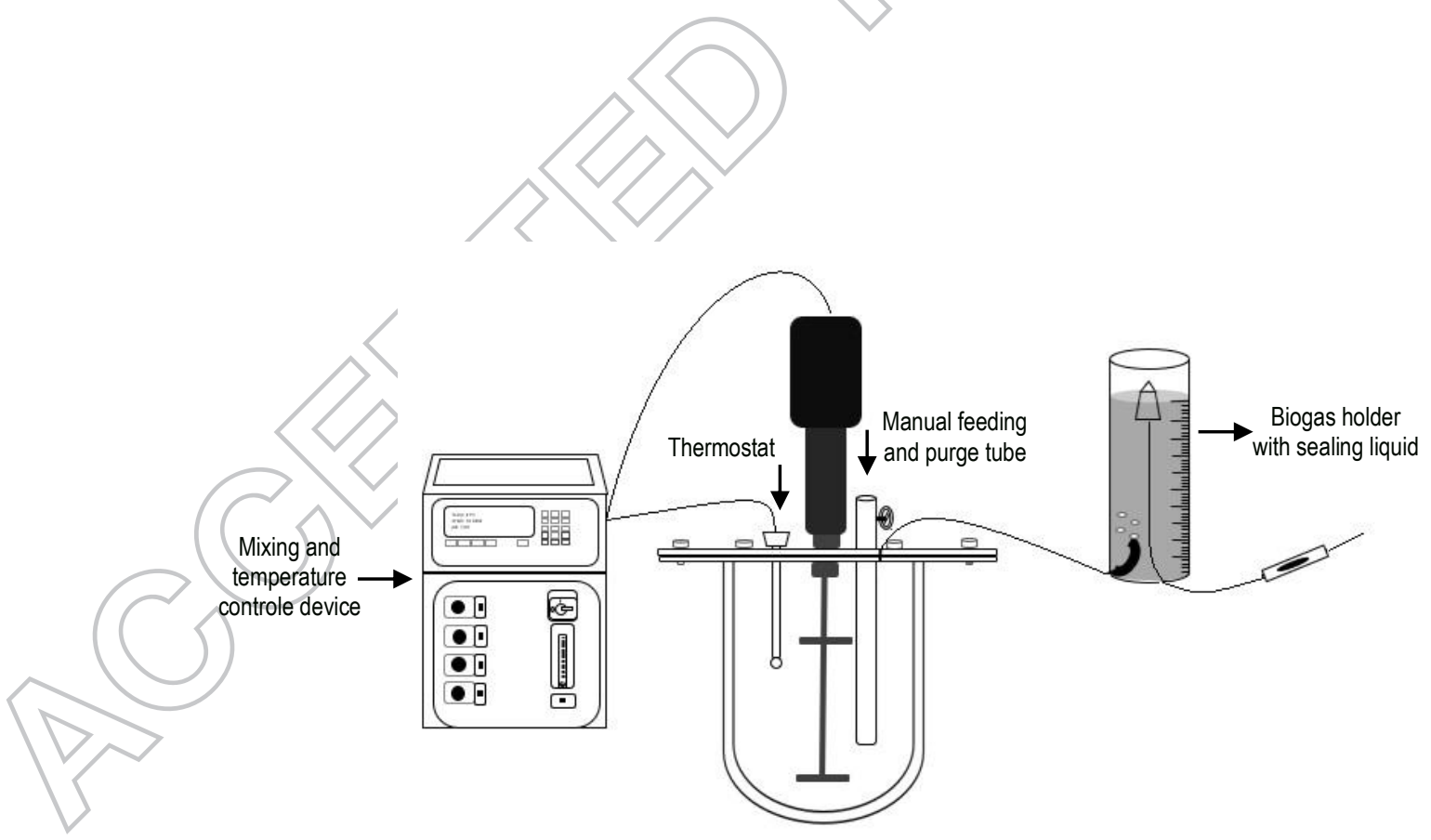

Figure 2 . 


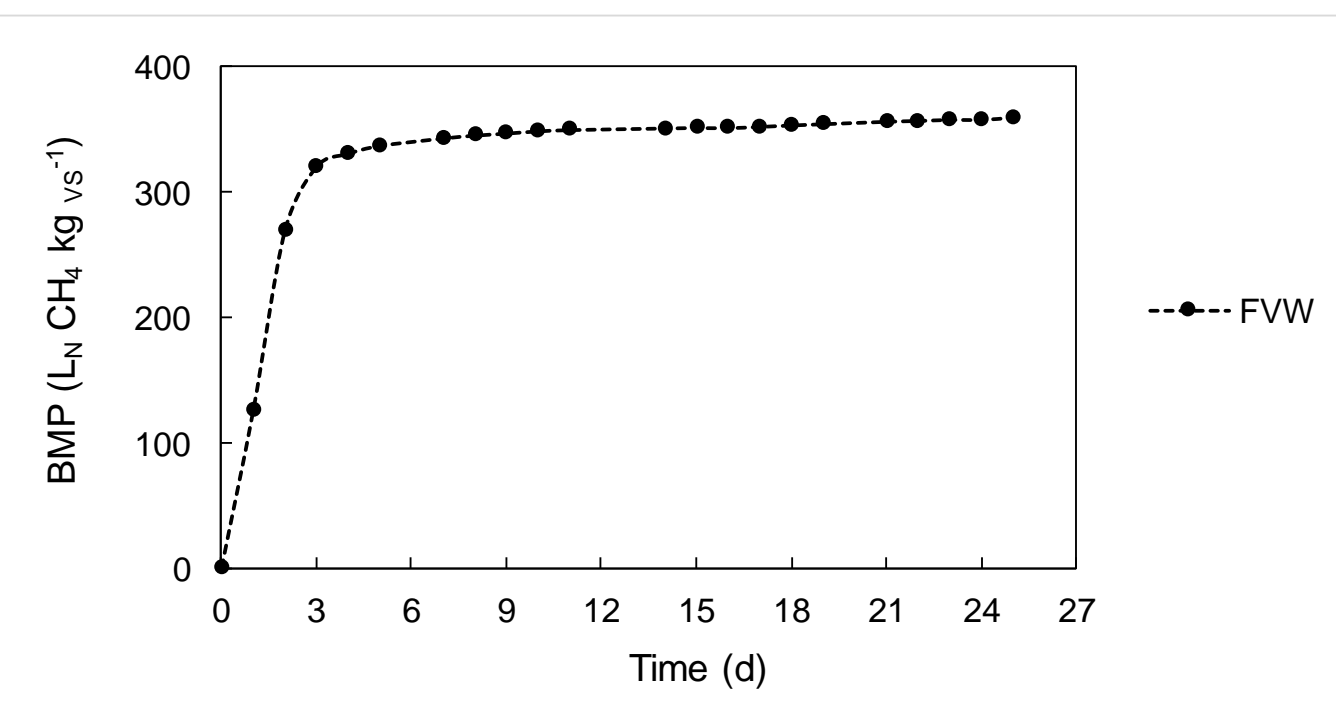

Figure 3. 

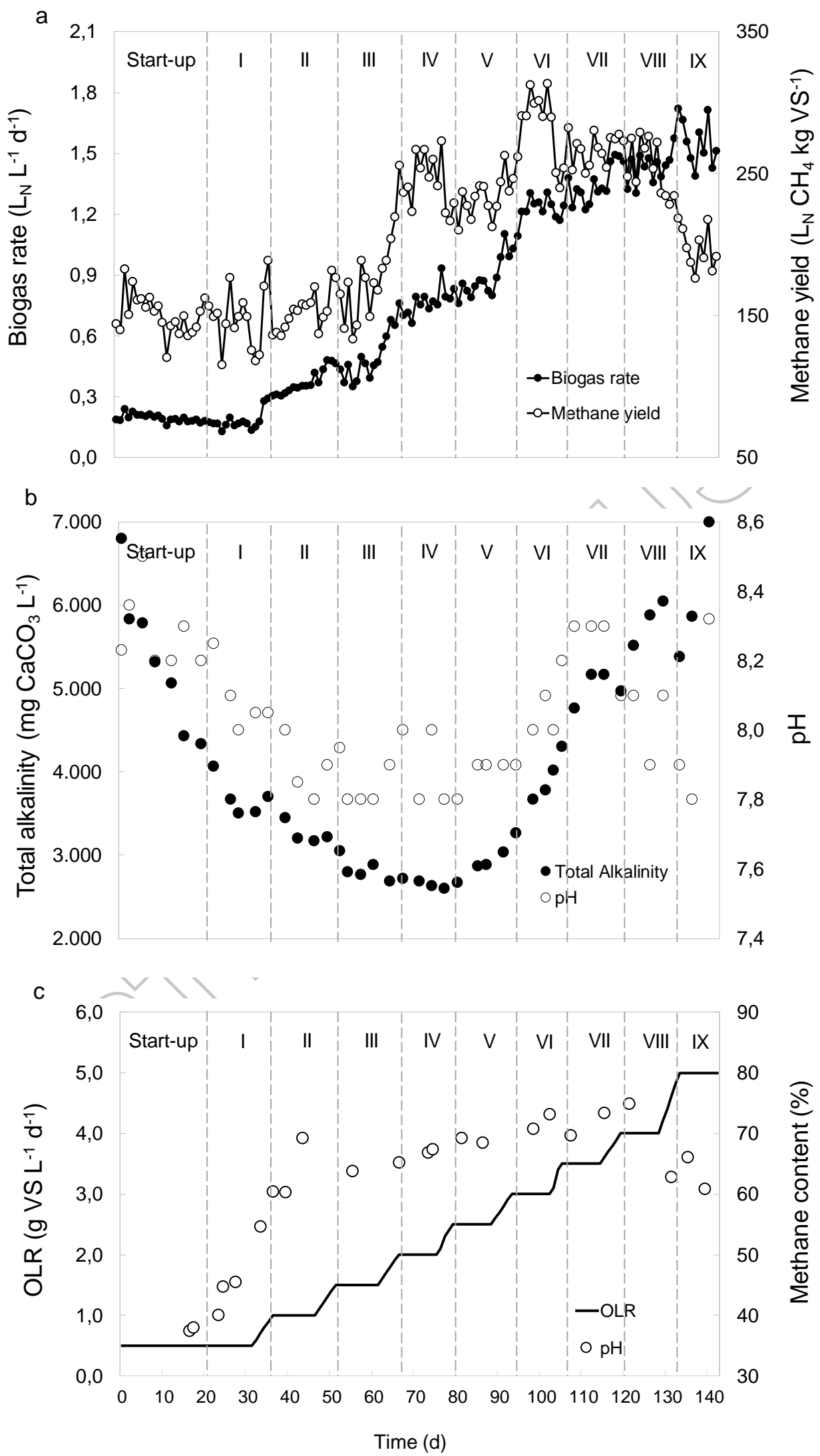

Figure 4 . 

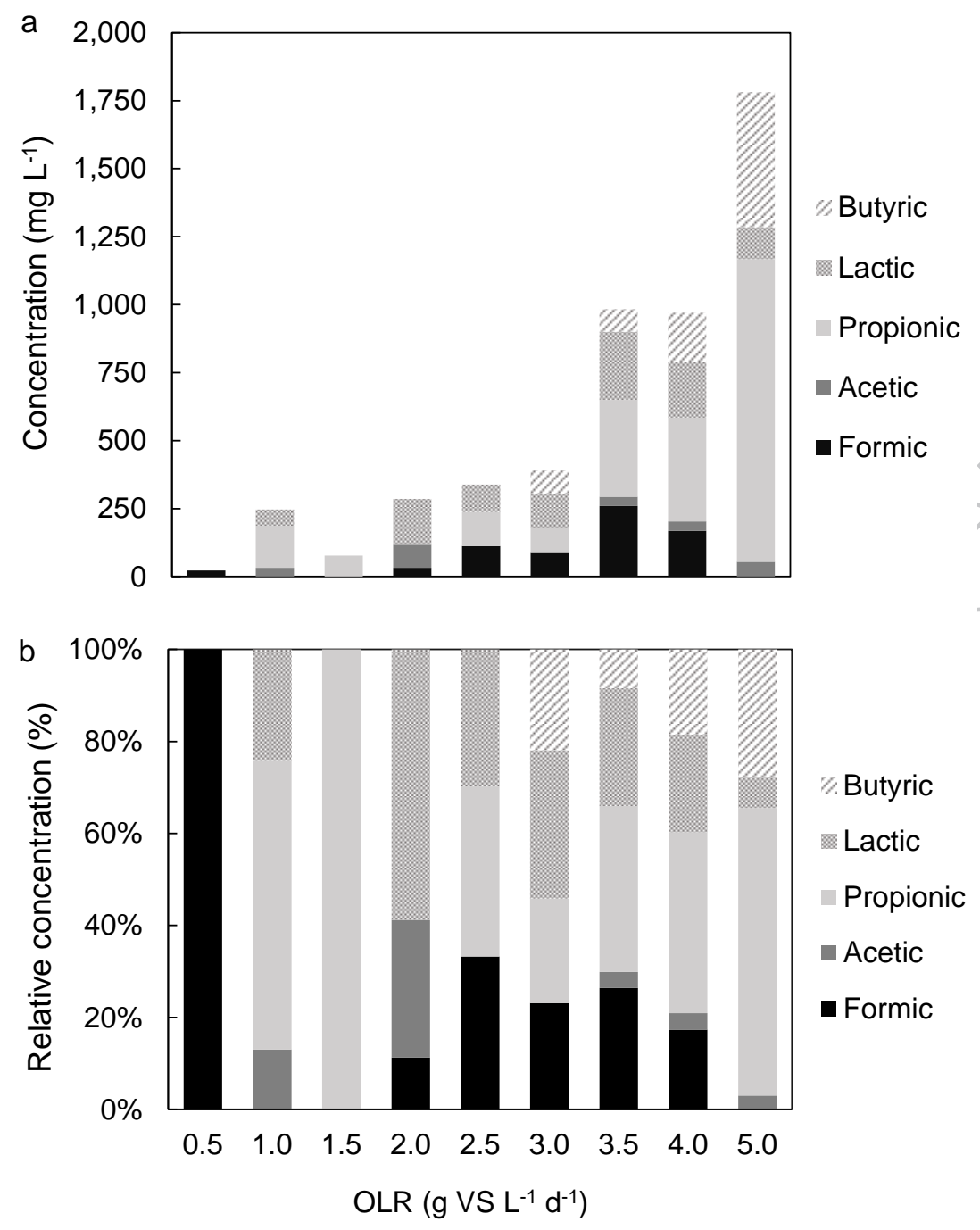

Figure 5. 
Table 1. Composition of fruit and vegetable waste used as a substrate

\begin{tabular}{|c|c|}
\hline Parameter & Mean $( \pm \mathrm{SD})$ \\
\hline Total solids $\left(\mathrm{g} \mathrm{kg}^{-1}\right)$ & $129( \pm 17)^{\mathrm{a}}$ \\
\hline Volatile solids $\left(\mathrm{g} \mathrm{kg}^{-1}\right)$ & $121( \pm 5)$ \\
\hline Density $\left(\mathrm{kg} \mathrm{L}^{-1}\right)$ & $1.03( \pm 0.02)$ \\
\hline $\mathrm{pH}$ & $3.9( \pm 0.03)$ \\
\hline Total Kjeldahl nitrogen (\% dry weight) & $2.2( \pm 0.1)$ \\
\hline Crude protein $(\% \mathrm{VS})$ & $15.8( \pm 0.6)$ \\
\hline Crude lipid (\%VS) & $2.7( \pm 0.1)$ \\
\hline Cellulose (\%VS) & $11.1( \pm 0.1)$ \\
\hline Hemicellulose (\%VS) & $11.4( \pm 0.3)$ \\
\hline Lignin (\%VS) & $3.8( \pm 1.4)$ \\
\hline Non-lignocellulosic carbohydrates (\%VS) & $55.2( \pm 0.8)$ \\
\hline $\mathrm{Co}\left(\mathrm{mg} \mathrm{L}^{-1}\right)$ & $1.35( \pm 0,27)$ \\
\hline $\mathrm{Cu}\left(\mathrm{mg} \mathrm{L}^{-1}\right)$ & \\
\hline $\mathrm{Fe}\left(\mathrm{mg} \mathrm{L}^{-1}\right)$ & $69( \pm 16.20)$ \\
\hline $\operatorname{Mo}\left(\mathrm{mg} \mathrm{L}^{-1}\right)$ & $<$ D.L. \\
\hline $\mathrm{Ni}\left(\mathrm{mg} \mathrm{L}^{-1}\right)$ & $0.27( \pm 0.001)$ \\
\hline $\mathrm{Se}\left(\mathrm{mg} \mathrm{L}^{-1}\right)$ & $<$ D.L. \\
\hline $\mathrm{Zn}\left(\mathrm{mg} \mathrm{L}^{-1}\right)$ & $5.73( \pm 1.29)$ \\
\hline
\end{tabular}

Table 2. Summary of anaerobic digestion performances

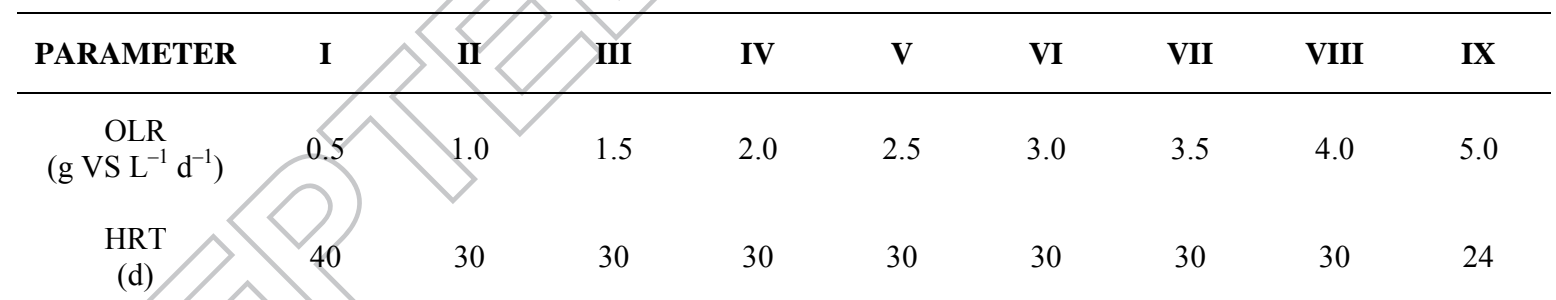
$\begin{array}{clllllllll}\text { Biogas rate } & 0.17 \pm 0.02 & 0.33 \pm 0.02 & 0.43 \pm 0.04 & 0.73 \pm 0.05 & 0.83 \pm 0.04 & 1.19 \pm 0.11 & 1.28 \pm 0.07 & 1.43 \pm 0.07 & 1.55 \pm 0.12\end{array}$ Methane yield $\left(\mathrm{L}_{\mathrm{N}} \mathrm{CH}_{4} \mathrm{~kg} \mathrm{VS}^{-1}\right)$

$151 \pm$

$214 \pm 11$

$164 \pm 16$

$247 \pm 14$

$228 \pm 10 \quad 285 \pm 26$

$262+14$

$267 \pm 13 \quad 198 \pm 17$

$\mathrm{CV}$

$(\%)$

10

7

10

5

9

5

5

7

$\mathrm{CH}_{4}$ Content

$(\%)$

$43 \pm 0$

$65 \pm 2.3$

$64 \pm 2.9$

$67 \pm 0.3$

$69 \pm 0.5$

$72 \pm 1$.

$72 \pm 2$

$75 \pm 0.1$

$64 \pm 3.7$

$\mathrm{pH}$

$$
8.1 \pm 0
$$

$7.9 \pm 0.1$

$7.8 \pm 0.1$

$7.9 \pm 0$.

$7.9 \pm 0$.

$8.0 \pm 0$.

$8.3 \pm 0$.

$8.1 \pm 0.1$

$8.1 \pm 0.3$

Total VFA (mg L ${ }^{-1}$ ) 
Total alkalinity

$\left(\mathrm{mg} \mathrm{L}^{-1}\right)$

$3,744 \pm 291 \quad 3,272 \pm 155 \quad 2,875 \pm 126 \quad 2,678 \pm 42 \quad 2,806 \pm 120 \quad 3,572 \pm 271 \quad 4,745 \pm 379 \quad 5,604 \pm 480 \quad 6,434 \pm 801$

$\begin{array}{cccccccccc}\text { IA:PA } & 0.10 & 0.13 & 0.12 & 0.09 & 0.13 & 0.13 & 0.13 & 0.14 & 0.13 \\ \text { VA:TA } & 0.15 & 0.18 & 0.15 & 0.10 & 0.13 & 0.12 & 0.09 & 0.11 & 0.10\end{array}$

OLR: organic loading rate; HRT: hydraulic retention time; CV: coefficient of variation related to biogas production; VS: volatile solids; VFA volatile fatty acids; IA:PA: intermediate alkalinity to partial alkalinity ratio; VA:TA: volatile acids ratio.

Table 3. Summary of trace elements in digestate for each operational phase

\begin{tabular}{cccccccccccc}
\hline $\begin{array}{c}\text { Parameter } \\
\mathrm{mg} \mathrm{L}^{-1}\end{array}$ & $\mathrm{I}$ & $\mathrm{II}$ & $\mathrm{III}$ & $\mathrm{IV}$ & $\mathrm{V}$ & $\mathrm{VI}$ & $\mathrm{VII}$ & $\mathrm{VIII}$ & $\mathrm{IX}$ & $\begin{array}{c}\text { Optimal values } \\
\text { reported in literature }\end{array}$ \\
\hline $\mathrm{Co}$ & 0.11 & 0.11 & 0.07 & 0.04 & 0.03 & 0.11 & 0.08 & 0.08 & 0.06 & $0.018-0.035[35]$ \\
$\mathrm{Cu}$ & 3.0 & 2.1 & 0.6 & 0.2 & 0.1 & 1.0 & 0.8 & 1.5 & 0.8 & $0.025[36]$ \\
$\mathrm{Fe}$ & 44.6 & 35.3 & 24.3 & 16.4 & 16.6 & 44.2 & 42.7 & 48.3 & 44.0 & $1.95[36]$ \\
$\mathrm{Ni}$ & 0.05 & 0.06 & 0.04 & 0.03 & 0.03 & 0.07 & 0.07 & 0.09 & 0.14 & $0.1[37]$ \\
$\mathrm{Zn}$ & 5.3 & 3.7 & 5.9 & 0.8 & 0.6 & 2.7 & 3.0 & 3.6 & 3.2 & $0.03-2[38]$ \\
\hline
\end{tabular}

